\title{
Tourist and Commercial Demand for Hotel/Motel Services
}

\author{
Michael J. Ellerbrock and Gary J. Wells*
}

INTRODUCTION

Though tourism is receiving increased attention in scientific literature, the accommodations sector lacks basic research on what factors most influence its economic behavior. Several fundamental questions exist: What determines consumer demand? What governs supply? How much does demand and/or supply change when the determinants change? How different are tourist and business travelers? What degree of competition exists in the industry? In particular, of what influence are room rates, gasoline prices and "bed" taxes?

One possible reason for the paucity of such analysis is that economists interested in theory may have assumed that classical market models are directly applicable to the lodging industry, thus negating any need for special consideration. Another explanation may be that hotel/motel operations have traditionally been reluctant to provide the necessary data for empirical analysis.

The study was undertaken to establish a theory of economic behavior in the lodging industry and to test it empirically. The goals were to enhance general understanding of the industry and to develop a predictive model for policy evaluation.

Researchers have illustrated the strong reliance of various states on tourism $(6,7,8,10,27,35)$ and urged continued analysis (16). Several authors have emphasized that accommodations may be the most important sector of the broader tourism industry $(1,13,19)$. Most work on the demand for lodging has focused on customer characteristics and preferences and the effectiveness of selected marketing techniques $(5,17,24,28$,

\#Though an important component of commerce and tourism, the hotel/motel industry has received little economic analysis, particularly in terms of predictive modeling. This paper proposes a theory of demand for hotel/motel services and presents the findings of an empirical test of the theory. Separate equations specify factors correlated with tourist and commercial demand, each reported in linear and logarithmic form. Price elasticities and gasoline cross-price elasticities are estimated and the impact of accommodation taxes are discussed.

*The authors are, respectively: Assistant Professor, Department of Agriculture, East Texas State University; and Associate Professor, Department of Agricultural Economics and rural Sociology, Clemson University. Grateful appreciation is expressed to James C. Hite for his theoretical and empirical input to this study. His contribution was substantial and very valuable. 
30, 31). Economic oriented studies have identified factors that influence demand, but the measurements used were on an ordinal scale rather than cardinal $(9,12,21,23,36)$. Similarly, of studies conducted on the supply of accommodations $(2,11,25,29)$, none developed models capable of quantifying supply response to changes in determinants.

Investigators have examined the fiscal impact of room taxes (33), the progressivity of such taxes (3), and the influence of the after-tax price on establishments' business $(3,20,26)$. Limitations include: an assumption of zero price elasticity of demand (33), analysis of resort establishments only (3), and estimation of travel-cost (rather than room rate) elasticity of demand $(20,26)$. Studies of gasoline price impacts on travel $(4,14,34)$ have not estimated cross-price elasticities of demand for accommodations, i.e. the percentage change in the quantity of lodging demanded given a percentage change in gasoline prices. Thus, a need exists for econometric estimation of a model that might explain the basic elements governing economic behavior in the industry.

\section{THEORETICAL MODEL}

The hotel/motel industry is composed of many firms, some of which operate more than one establishment. Location is unique for each establishment and the package of amenities (swimming pool, color TV, golf privileges, etc.) varies; thus, the industry cannot be construed to reflect the conditions of a perfectly competitive market. Rooms at one establishment (est.) are less than perfect substitutes for rooms at others. It can, therefore, be assumed that the demand curve facing any given establishment slopes downward and to the right. Following classical economic theory, it is hypothesized that the demand for accommodations at establishment $\mathrm{i}$ in time period $\mathrm{t}$ can be expressed:

$$
Y_{i t k}=f\left[P_{i t k}, X_{k}, A_{i t k}, L_{i k}, M_{i k}, P_{c t k}, P_{s t k}, I_{t k}, Z_{t k}, A_{i t-12 K}\right]
$$

where: $Y_{\text {itk }}=\%$ occupancy rate of the $i^{\text {th }}$ est. in the $t^{\text {th }}$ time period in the
$\mathrm{k}^{\text {th }}$ region,

$\mathrm{P}_{\mathrm{itk}}=$ avg. rental rate $(\$)$ of the $\mathrm{i}^{\text {th }}$ est. in the $\mathrm{t}^{\text {th }}$ time period in the $\mathrm{k}^{\text {th }}$ region,

$\mathrm{X}_{\mathrm{k}}=$ season,

$\mathrm{A}_{\mathrm{itk}}=\mathrm{adv}$. exp. by the $\mathrm{i}^{\mathrm{th}}$ est. in the $\mathrm{t}^{\mathrm{th}}$ time period in the $\mathrm{k}^{\mathrm{th}}$ region,

$\mathrm{L}_{\mathrm{ik}}=$ location of the $\mathrm{i}^{\text {th }}$ est. in the $\mathrm{k}^{\text {th }}$ region,

$\mathrm{M}_{\mathrm{i} k}=$ amenities of the $\mathrm{i}^{\text {th }}$ est. in the $\mathrm{k}^{\mathrm{th}}$ region,

$\mathrm{P}_{\mathrm{ctk}}=$ price of complementary goods in the $\mathrm{t}^{\text {th }}$ time period in the $\mathrm{k}^{\text {th }}$ region, 
$\mathrm{P}_{\mathrm{stk}}=$ price of substitute goods in the $\mathrm{t}^{\text {th }}$ time period in the $\mathrm{k}^{\mathrm{th}}$ region,

$I_{t k}=$ income in the $t^{\text {th }}$ time period in the $\mathrm{k}^{\text {th }}$ region,

$Z_{\mathrm{t} k}=$ population in the $\mathrm{t}^{\text {th }}$ time period in the $\mathrm{k}^{\text {th }}$ region,

$\mathrm{A}_{\mathrm{it}-12 \mathrm{k}}=\mathrm{adv}$. exp. by the $\mathrm{i}^{\text {th }}$ est. in the $\mathrm{t}-12^{\text {th }}$ time period in the $\mathrm{k}^{\text {th }}$ region,

$\mathrm{t}=$ month

A competitive firm's supply curve is its marginal cost curve above its average variable cost curve. It is assumed that, in the short run, hotels and motels determine the number of rooms they are willing to rent according to the marginal costs of renting them. It seems, a priori, that the marginal cost of renting an additional room is relatively stable throughout a certain range of rooms. Marginal costs may increase most when an additional wing of existing rooms are opened and/or additional employees are needed. Thus, the short-run "economic" supply of rooms for rent may be a function of labor and utility costs. A traditional and continuous curve is assumed in the analysis, though there are some reasons to suspect the curve may be "stepped" or have a series of discontinuous, relatively flat sections.

It is theorized that the economic supply of accommodations by establishment $\mathrm{i}$ in time period $\mathrm{t}$ can be expressed:

$$
Z_{\text {itk }}=f\left[P_{i t k}, Y_{i t-12 k}, W_{t k}, R_{i t k}, B_{t k}, C_{t k}\right] \text {, }
$$

where:

$\mathrm{Z}_{\mathrm{itk}}=$ no. of rooms available for occupancy in the $\mathrm{i}^{\mathrm{th}}$ est. in the $\mathrm{t}^{\text {th }}$ time period in the $\mathrm{k}^{\text {th }}$ region,

$\mathrm{P}_{\mathrm{itk}}=$ avg. rental rate $(\$)$ of the $\mathrm{i}^{\mathrm{th}}$ est. in the $\mathrm{t}^{\mathrm{th}}$ time period in the $\mathrm{k}^{\mathrm{th}}$ region,

$\mathrm{Y}_{\mathrm{it}-12 \mathrm{k}}=\%$ occupancy rate of the $\mathrm{i}^{\text {th }}$ est. in the time period $\mathrm{t}-12$ in the $\mathrm{k}^{\text {th }}$ region,

$\mathrm{W}_{\mathrm{t}}=$ prevailing wage rate in the $\mathrm{t}^{\text {th }}$ time period in the $\mathrm{k}^{\mathrm{th}}$ region,

$\mathrm{R}_{\mathrm{itk}}=$ physical supply of rooms in the $\mathrm{i}^{\text {th }}$ est. in the $\mathrm{t}^{\text {th }}$ time period in the $\mathrm{k}^{\text {th }}$ region,

$\mathrm{B}_{\mathrm{tk}}=$ avg. cost of utilities in the $\mathrm{t}_{\mathrm{th}}$ time period in the $\mathrm{k}^{\mathrm{th}}$ region,

$\mathrm{C}_{\mathrm{tk}}=$ prevailing rate of interest in the $\mathrm{t}^{\text {th }}$ time period in the $\mathrm{k}^{\mathrm{th}}$ region. 
An interesting question concerns price. Static economic demand curves assume that price is a causal factor and quantity demanded as well as quantity supplied are the result of price in market transactions (38). However, in the sale of many goods, price itself is influenced by other factors, including the quantity demanded in the current or previous time periods, and under objectives of profit maximization or breaking-even (37). In 'econometric terms, price can be an endogenous factor determined simultaneously with quantity demanded and quantity supplied by several exogenous variables. In such cases, all of the factors comprise a simultaneous system in which the endogenous variables (quantity demanded, quantity supplied, price) are functions of "pre-determined" exogenous variables, pre-determined meaning the values are established before the system determines the endogenous variables. If room rates are influenced by demand and/or supply, a simultaneous system of equations may be needed to capture the role of price.

\section{DATA}

A survey was distributed to the 125 member establishments of the South Carolina Innkeepers' Association (SCIA) which solicited monthly information from 1973 through July 1979 on number of rooms rented, occupancy rates, room rates, location, amenities, services, advertisement expenditures, national chain affiliation, and duration of the tourist season. Twenty-eight establishments responded, 22 of whose questionnaries were fully completed and useful, giving a total of 784 monthly observations. Though the sample represents only three percent of all establishments in South Carolina and 18 percent of all member establishments of the SCIA, the sample does present a cross-section of the state geographically and in the types of establishments. A strength of the data is that several respondents provided four to seven years of information. Table 1 lists the 52 independent variables that were examined individually and in combination for their amount of correlation with four dependent variables.

Limitations of the data were: 1) sample size; 2) some data were available only in annual terms; 3) historical gasoline prices were not available for any South Carolina cities; 4) gasoline prices in Atlanta, Georgia were specified by major and independent dealers for 1973-76, but further specified by full-serve and self-serve for 1977-79 (18); 5) advertising expenditures were available for only the 12 most recent months; and 6) historical observations on occupancy rates did not allow estimation of a true economic supply curve because operators were able to exercise some monopoly power via the downward sloping demand curves discussed above. In actuality, only a quasi-supply or "response" curve could be estimated.

\section{METHODOLOGY}

The first step was use of the Maximum $\mathrm{R}^{2}$ Improvement Technique to determine which independent variables were most highly correlated with each of the dependent variables. Limited to 20 variables, the procedure 
TABLE 1

VARIABLES EXAMINED IN ECONOMETRIC MODEL

Dependent:

A. No. of rooms rented by est. to tourists by month

B. No. of rooms rented by est. to commercial travelers by month

C. $(\mathrm{A}+\mathrm{B})$

D. \% occupancy rate by est. by month

Independent:

1. Actual revenue per room by est. per day

2. Real (deflated) price by est. per day

3. Prime interest rate by month

4. Minimum wage by month

5. Newspaper adv. exp. by est. per month

6. Magazine adv. exp. by est. per month

7. Billboard adv. exp. by est. per month

8. Brochure adv. exp. by est. per month

9. Radio adv. exp. by est. per month

10. T.V. adv. exp. by est. per month

11. Misc. adv. exp. by est. per month

12. $\Sigma(5 \ldots 11)$

13. SC income per capita per yr.

14. NC income per capita per yr.

15. FL income per capita per yr.

16. GA income per capita per yr.

17. SC pop. by yr.

18. NC pop. by yr.

19. FL pop. by yr.

20. GA pop. by yr.

21. Unemployment rate by SC county by month

22. Avg. hourly wage rate in H/M sector by SC county by yr.

23. No. of est. by SC county by yr.

24. Pop. of SC county by yr.

25. Lag of (State Avg. \% Occupancy Rate-Est. \% Occupancy Rate)

26. No. of campgrounds by SC county by yr.

27. Avg. price of campgrounds by SC county by yr.

28. Nat'l. avg. price of gasoline by month

29. Lowest price of gasoline available in Atlanta, GA by month

30. $(28-29)$

(Dummy)

31. Year

32. Month

33. On-season

34. In municipality

35. Near interstate hwy.
42. Has golf

43. Has beachfront

44. Has tennis courts

45. Has coffee shop

46. Has restaurant 
TABLE 1.-CONTINUED

36. Nat'l. franchise

37. Advance registration

38. Member American Automotive Association

39. Has swimming pool

40. Has black \& white T.V.

41. Has color T.V.
47. Has bar/club

48. Has live entertainment

49. Has room service

50. $\Sigma(39 \ldots 49)$

51. Has tourist season

52. Has seasonal rates

chose the best predictors based on their marginal contribution to the $\mathrm{R}^{2}$ statistic of the multiple regression equations. A correlation matrix was then computed to assess the amount of intercorrelation among independent variables in order to reduce the problem of multicollinearity. A correlation coefficient, $r$, was considered to reflect an unacceptably high degree of correlation between two variables if:

$$
0.5<\mathrm{r} \leq 1.0 \text {, or }-1.0 \leq \mathrm{r}<-0.5
$$

Multiple linear regression expressions of total demand, commercial demand, tourist demand and response were then estimated with ordinary least squares (OLS) statistics. Unsatisfactory results were obtained, particularly with the demand equations. Signs opposite to what theory would predict appeared on the coefficients of several key variables: price, income, on-season, advertisment expenditures, gasoline prices, beachfront access, live entertainment, restaurant, and interstate highway location.

Failure to identify an inverse relationship between price and the quantity demanded led to suspicion of a simultaneous situation where price and quantity were determined in the industry simultaneously. Simultaneous systems of equations were then estimated in linear and double loglinear form. The statistical concern peculiar to simultaneous systems is that the explanatory endogenous variable (in this case, price) is correlated with the disturbance term in the structural equations since the endogenous variable itself is a function of one or more of the other endogenous variables plus any other factors.

A longstanding issue in econometric analysis has been the merits of combining cross-section data with time-series data. ${ }^{1}$ It was decided to aggregate the data because a time-series analysis would have necessitated dropping several years of data from those establishments that provided more than one and one-half years of data in order to incorporate crosssectional information in estimating separate equations for each firm. The

\footnotetext{
'Laughunn, who researched the issue for his doctoral dissertation, feels there is no theoretical explanation as to why combined data has predictive power superior to time-series data alone in some cases and inferior predictive capabilities in other cases. Laughhunn concluded, "... that there is nothing inherent in either methodology which necessarily implies best predictors" (15). Marschak (22) and Tobin (32) found that combined data reduced the standard errors of the parameter estimates and minimized the danger of spurious parameter estimates due to serial correlation.
} 
TABLE 2

SIMULTANEOUS REGRESSION RESULTS

\begin{tabular}{|c|c|}
\hline \multirow{3}{*}{ Commercial Demand = } & Three-Stage Least Squares Estimates for Linear Model \\
\hline & $\begin{array}{l}2,657.69-180.19(\text { Real Price })^{\mathrm{a}}+\underset{(2.79)}{1.92(\text { Pop. in County) }-67.50(\text { In Munic. })-6.60} \\
(2,478.87)(102.30)\end{array}$ \\
\hline & 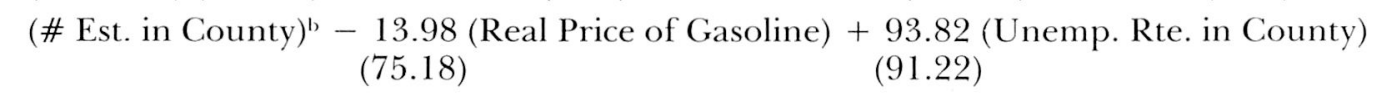 \\
\hline \multirow[t]{5}{*}{ Tourist Demand $=$} & 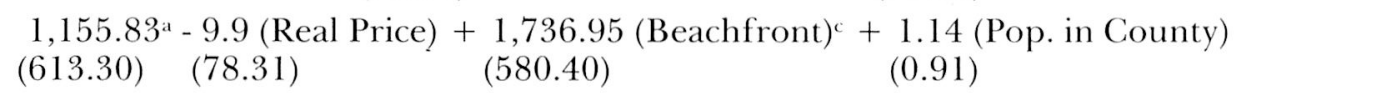 \\
\hline & 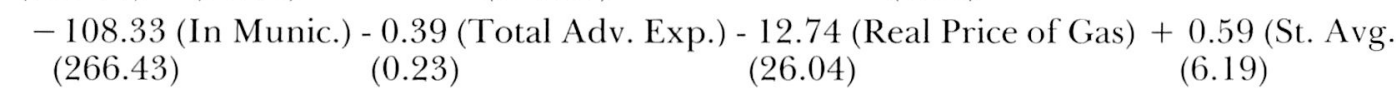 \\
\hline & Occ. Rte. - Est. Occ. Rte. $)_{t-12}$ \\
\hline & $\begin{array}{c}2,663.76+\underset{(59.91)}{22.37} \text { (Real Price) }-62.24 \text { (Prime Int. Rte.) }-688.90(\text { Avg. Wage in H/M } \\
(996.02) \\
(59.76)\end{array}$ \\
\hline & $\begin{aligned} &\text { Sector })^{\mathrm{b}}+ 0.63(\# \text { Rooms Rented })_{\mathrm{t}-12}^{\mathrm{c}} \\
&(0.16)\end{aligned}$ \\
\hline
\end{tabular}


TABLE 2.-CONTINUED

\begin{tabular}{|c|c|}
\hline \multirow{3}{*}{ LOG Comm. Dem. = } & Two-Stage Least Squares Estimates for Double Log-Linear Model \\
\hline & $11.57^{\mathrm{a}}-2.36 \mathrm{LOG}(\text { Real Price })^{\mathrm{a}}-0.23$ LOG (Pop. in county) -0.17 (In Munic.) -0.68 \\
\hline & $\begin{array}{l}\left.\text { (\# Est. in County) }^{\mathrm{a}}-3.38 \mathrm{LOG} \text { (Real Price of Gasoline) }\right)^{a}+\underset{(0.20)}{0.06 \mathrm{LOG} \text { (Unemp. Rte. in }} \\
\text { County) } \\
(0.61)\end{array}$ \\
\hline LOG To & 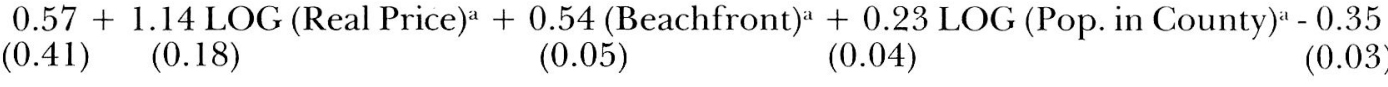 \\
\hline
\end{tabular}

$\left(_{\text {In Munic. }}^{a}-0.13 \text { LOG (Tot. Adv. Exp.) }\right)^{a}+0.72$ LOG (Real Price of Gasoline) ${ }^{a}-0.0006$ (St. (7) $(0.01)$

$(0.23)$

$(0.001)$

Avg. Occ. Rte. - Est. Occ. Rte. $)_{t-12^{a}}$

LOG Response $=3.08^{\mathrm{a}}+0.01 \mathrm{LOG}($ Real Price $)-0.08$ LOG (Prime Int. Rte. $)-0.32 \mathrm{LOG}($ Avg. Wage in H/M

$\begin{array}{llll}(0.07) \quad(0.06) & (0.07) & (0.10)\end{array}$

Sector $)^{\mathrm{a}}+\underset{(0.000007)}{0.0002}$ LOG (\# Rooms Rented $)_{\mathrm{t}-12 \mathrm{a}} \mathrm{a}$

$\mathrm{R}^{2}=0.402$

F Value $=45.85$, Prob. $>\mathrm{F}=0.0001$

Note: Number of Observations $=784$. Standard errors are in parentheses.

aDenotes significance at the 0.10 level.

${ }^{b}$ Denotes significance at the 0.05 level.

'Denotes significance at the 0.01 level. 
TABLE 3

ESTIMATES OF DEMAND ELASTICITIES

\begin{tabular}{lccc}
\hline \hline $\begin{array}{c}\text { Model } \\
\text { Form }\end{array}$ & $\begin{array}{c}\text { Commercial } \\
\text { Demand }\end{array}$ & $\begin{array}{c}\text { Tourist } \\
\text { Demand }\end{array}$ & $\begin{array}{c}\text { Total Firm } \\
\text { Demand }^{*}\end{array}$ \\
\hline Linear & \multicolumn{2}{c}{ Price Elasticities } & \\
Logarithmic & $-2.56^{c}$ & -0.13 & -0.97 \\
- & Gasoline Cross-Price Elasticities & -1.10 \\
Linear & -0.0051 & -0.008 & -0.03448 \\
Logarithmic & $-3.38^{c}$ & $+0.72^{c}$ & -0.0027 \\
\hline
\end{tabular}

"Significance level not calculable.

'Denotes significance at 0.01 level.

time-series analysis, with allowance for cross-sectional influences among establishments, would only include observations on each firm from January 1978 through July 1979. Future attempts to model basic economic relationships in the industry using time-series single firm equations would be of interest.

\section{EMPIRICAL RESULTS}

The linear model provided the most theoretically defensible estimates of the direction of relationships, whereas the double log-linear model gave more statistically significant results. Table 2 presents the findings. The real price variable in both models is a predicted real price estimated as a function of all the exogenous variables, as explained in the methodology section. It thus serves as a proxy for actual room rates.

Demand elasticities were calculated from the coefficients in each model and are presented in Table 3. An elasticity is defined as a percentage change in the quantity demanded resulting from a given percentage change in an explanatory variable, in this case price and gasoline prices. Elasticities were calculated because of the apparent recursive nature of the model.

\section{CONCLUSIONS}

For the sake of brevity, the main conclusions are listed numerically:

\section{Demand}

1. The best predictor of tourist demand is beachfront location, defined as "walking access to a beach without having to cross a paved road." It is associated with the rental of 1,737 rooms per month, all other things being equal, and the estimate is significant at the 0.01 level. 
2. Price has a clearly negative impact on commercial travelers. Information gained through repeat business makes them sensitive to prices, apparently outweighing the tendency of some to splurge while on expense accounts. Operators should thus consider directing discount programs toward commercial travelers in order to spur business.

3. Price's impact on tourists is ambiguous. Given a preferred location and "class" of hotel or motel, tourists may not make the effort required to obtain information on competing prices. Furthermore, the rental rate of a room is only one part of the price of a trip the tourist considers.

4. Population has a positive impact on tourist demand, but an unclear impact on commercial demand. This might indicate that people are increasingly vacationing near their home and that commercial travelers seek lodging outside of densely populated areas. Both findings are supported by conclusions five and six.

5. Gasoline prices have had a negative impact on commercial demand, but an unclear impact on tourists. It is possible that reductions in occupancy rates from fewer long-distance tourists have been partially offset by: a) increased visitation from local and short-distance travelers, and b) increased visitor lengths-of-stay. Also, in the period of analysis, travelers may have increased their travel due to long-run expectations of continued gas price rises.

6. Municipal location has a negative relationship with tourist and commercial demand. Both types of travelers may prefer populous areas, but seek to avoid lodging in central business districts.

7. Total advertisement expenditures are inversely correlated with tourist demand possibly because the busiest establishments do not need to advertise much and/or high expenditures may be characteristic of establishments trying to improve occupancy rates; or due to a "free rider" phenomenon, i.e. all establishments in a given community benefit, to some extent, from advertising by a few establishments. If it had been possible to test the lagged effect of advertising expenditures, that relationship may have been positive.

8. The number of establishments per county is inversely correlated with commercial demand, likely a reflection on heightened competition. The number of establishments, rather than the number of rooms per county, was used as a measure of competition because travelers are more likely to base their expectations of price on the number of establishments, but not necessarily on the number of rooms because a few large establishments may function in a less competitive atmosphere (i.e. as oligopolies or monopolistically competitive firms) than many small establishments.

9. Unemployment rate per county has an unclear effect on tourist and commercial demand. It was examined as a measure of the level of business activity in an area. Employment per county, also a measure of business activity, was not tested because of its interrelatedness with population per county. 


\section{Supply}

10. Supply response in both models is most sensitive to average wage rates in the lodging sector, a proxy for variable costs, i.e. costs that vary according to the level of production in the short run.

11. A statistically significant predictor is the number of rooms rented twelve months earlier, an indication that operators may set output according to some pre-determined objective rather than according to the going price level, which was not statistically significant.

12. Supply response was found to be inversely correlated with the prevailing prime interest rate, a proxy for fixed costs, i.e. costs invariant with the level of production in the short run. However, in neither model can the coefficient be assumed to be unequal to zero.

\section{Elasticities of Demand}

13. Possibly for reasons discussed in conclusions 2, 3 and 5, commercial travelers are more responsive to changes in room rates and gasoline prices. Total firm demand appears to have: a) unitary price elasticity, i.e. price movements are followed by proportional changes in quantity demanded; and b) very inelastic response to gasoline price changes, i.e. a given increase in gasoline prices is correlated with a less than proportional drop in occupancy rates.

\section{Accommodations Tax}

14. The price findings allow estimation of only a maximum potential impact on occupancy rates of an accommodations tax, whether excise or a percentage rate, because the estimated price elasticities of demand assume that only a given establishment raises its price. Establishments that would be hurt most are higher priced units, those bordering cities or counties without the tax, and establishments along state boundaries. Within given markets, consumers may shift down to lower priced accommodations if the tax is a percentage rate. Some lower priced units may thus be net benefitors from the tax. Furthermore, to lose business, three conditions must hold: a) establishments in the next city, county or state have prices lower than the total with-tax cost (including the costs of added travel); b) consumers have knowledge of the inter-area price differentials; and c) lodging in the without-tax area is a satisfactory substitute for lodging in the with-tax area. It is, therefore, concluded that implementation of an accommodations tax across all establishments in a market would result in a considerably less fall in occupancy rates than predicted by these models.

\section{REFERENCES}

1. Arbel, Avner and Abraham Pizam. "Some Deter minants of Urban Hotel Location: The Tourists" Inclinations." Joumal of Travel Research 15(3): 18-22. 1977.

2. Arbel, Avner and Paul Grier. "The Risk Structure

of the Hotel Industry." The Cornell H.R.A. Quarterly. November: 15-22. 1978.

3. Combs, J. Paul and Barry W. Elledge. "Effects of a Room Tax on Resort Hotel/Motels." National Tax Joumal. 22(2): 201-207, 1979. 
4. Corsi, Thomas M. and Milton E. Harvey. "Changes in Vacation Travel in Response to Motor Fuel Shortages and Higher Prices." Journal of Travel Research. 17(4): 7-11. 1979.

5. D'Amore, L. J. "Forecasting in Tourism and Outdoor Recreation." Journal of Travel Research. 15(4): 36-37. 1977

6. Discover America Travel Organization. Travel: An Engine of Employment. Washington, D.C. 1977.

7. Doering, Thomas R. "A Reexamination of the Relative Importance of Tourism to State Economies." Journal of Travel Research. 15(1): 13-17. 1976.

8. Ellerbrock, Michael J. and James C. Hite. "Factors Affecting Regional Employment in Tourism in the United States." Joumal of Travel Research. 18(3):26$32,1980$.

9. Fisk, George. Leisure Spending Behavior. Philadelphia: University of Pennsylvania Press. 1963.

10. Frechtling, Douglas C. "Travel as an Employer in the State Economy." Journal of Travel Research. 15(4): 8$12,1977$.

11. Gilbert, Hamlin. "The Travel-Lodging Interface." The Comell H.R.A. Quarterly. November: 14-21. 1976.

12. Gum, Russell L. and William E. Martin. "Structure of Demand for Outdoor Recreation." Land Economics. 53: 41-55. 1977.

13. Gunn, Clare A. Tourism Planning. New York: Crane Russak. 1979

14. Kratt, John and Mark Rodekohr. "Regional Demand for Gasoline: A Temporal Cross-Section Specification. Journal of Regional Science. 18(1): 45-56. 1978.

15. Laughhunn, D. J. On the Predictive Value of Combining Cross-Section and Time-Series Data in Empiricl Demand Studies. Urbana: University of Illinois Bulletin. 66(73). 1969.

16. Leisure Systems, Inc. Tourism in the United StatesPotentials and Problems. Fort Lauderdale, Florida. 1976.

17. Liepa, R. "Methodology for Short-Term Forecasts of Tourism Flows." Canadian Government Office of Tourism. 4. 1977.

18. Lundberg, Dan. "Platt's/Lundberg Report." Lundberg Letter. North Hollywood, California. Monthly publication.

19. Lunberg, Donald E. The Tourist Business. Boston: CPI Publishing Company, Inc. 1976

20. Mak, James and Edward Nishimura. "The Economics of a Hotel Room Tax." Journal of Travel Research. 17(4): 2-6. 1979.

21. Market Facts. "Why Travelers Choose Hotels and Motels." Lodging. September: 48-52. 1977.

22. Marschak, Jacob. "Money Illusion and Demand Analysis." Review of Economic Statistics. 25(1): 40-48. 1943 .
23. Mayo, Edward J. "The Psychology of Choice in the Lodging Market-Study of Price-Value Decisions by Auto Vactioners." Conducted for the 3M National Advertising Company. Department of Marketing. University of Notre Dame. 1973.

24. Morphis, Gene S. "Load-Factor Pricing and the Lodging Industry." The Cornell H.R.A. Quarterly. November: 34-37. 1978.

25. Rose, Alan P. Quote. South Carolina Innkeepers Association. Columbia, South Carolina. April 6, 1980 .

26. Roueche, Leonard. "Transportation Prices and Tourism: A Case Study." Journal of Travel Research. 16(3): 25-26. 1978.

27. Royer, Lawrence E., Stephen F. McCool and John D. Hunt. "The Relative Importance of Tourism to State Economics." Journal of Travel Research. 21 (4): 13-16. 1974

28. Saran, A. "Economic Determinants of Tourist Demand: A Survey." Tourist Review. 3(1). 1978.

29. Smith, Stephen L. "Room for Rooms: A Procedure for the Estimation of Potential Expansion of Tourist Accommodations." Journal of Travel Research. 15(:4): 26-29. 1977.

30. Sunday, A. A. "Foreign Travel and Tourism Prices and Demand." Annals of Tourism Research. 5(3). 1978.

31. Taylor, G. D. and M. Doctoroff. "An Approach to an Integrated Forecasting System for a National Tourism Office." Canadian Government Office of Tourism. 1974.

32. Tobin, James. "Statistical Demand Function for Food in the U.S.A." Journal of Royal Statistical Society. A(113): 113-141. 1950 .

33. Ulbrich, Holly H. "The Proposed Hotel-Motel Accommodations Tax." Prepared for the Special Legislative Study Committee on Alternatives for Financing County and Municipal Government. Clemson University Working Paper 102078. October 1978.

34. United States Travel Data Center. Energy Shortage Travel Impact Survey: Summary Report. Washington, D.C. 1974 .

35. United States Travel Data Center. The Impact of Travel on State Economies. Washington, D.C. 1978.

36. Wilks, John T., Jr. Budget Motels and the Lodging Industry. Econo-Travel Motor Hotel Corporation. Norfolk, Virginia. June 1977.

37. Weston, J. Fred. "Pricing Behavior of Large Firms." Western Economic Journal. 10(1): 1-18. 1972.

38. Working, E. J. "What Do Statistical Demand Curves Show?" Readings in Price Theory. Chicago: Richard D. Irwin, Inc. 1952. 